\title{
Gasification and pyrolysis of different biomasses in lab scale system: A comparative study
}

\author{
W. Gądek ${ }^{1 a}$, A. Mlonka-Mędrala², M. Prestipino ${ }^{3}$, P. Evangelopoulos ${ }^{4}$, S. Kalisz¹, W. Yang ${ }^{4}$ \\ ${ }^{1}$ Silesian University of Technology, Institute of Power Engineering and Turbomachinery, 44100 Gliwice Konarskiego 20, Poland \\ ${ }^{2}$ AGH University of Science and Technology, Faculty of Energy and Fuels.30059 Krakow Mickiewicza 30, Poland \\ ${ }^{3}$ University of Messina, Department of Engineering. C.da Di Dio, 98166, Messina, Italy \\ ${ }^{4}$ Royal Institute of Technology, Department of Material Science and Engineering, 10044 Stockholm Brinellvägen 23, Sweden
}

\begin{abstract}
Gasification and pyrolysis are very promising technologies for clean energy production especially from low rank fuels. Biomass and wastes with high chlorine, alkali and even heavy metals content are fuels preferential for thermal utilization. However, several problems during combustion in conventional steam boilers occurs e.g. slagging, fouling, chlorine corrosion, boiler efficiency deterioration. New efficient and cost effective technologies are needed, even in small-scale applications. The main objective of this work was to compare the thermochemical behaviour and process parameters effects of different biomass under air gasification and pyrolysis conditions. Three important fuels for European power industry were selected: woody biomass and two residual biomass, such as oat straw and dried citrus wastes. In order to evaluate the possibility to use different feedstocks or to combine and/or integrate them in thermochemical processes, a comparison among typical and untypical feedstocks is needed. Tests performed on small scale fixed bed reactor show the gas yield, its composition and LHV parameter. The results were performed in Royal Institute of Technology $(\mathrm{KTH})$ in Sweden during BRISK program (Biofuels Research Infrastructure for Sharing Knowledge).
\end{abstract}

\section{Introduction}

Nowadays renewable sources of energy are of great importance. This is strongly associated both with the climate change and the current policies of EU. According to the "2030 Climate and Energy Framework", which extends the existing EU climate policy, the main goal is to reach at least $40 \%$ reduction of greenhouse gasses by 2030 comparing with the values of 1990 [1]. Furthermore, another goal set until the 2030 is to increase the share of renewable sources for energy production to $27 \%$ [1]. EU regulations can strongly influence the research community for targeting more efficient and more environmental friendly energy production. Biomass has the largest share in the renewables market and great potential for clean energy production [2]. Biomass is considered to be a "carbon neutral" fuel, considering that the emitted $\mathrm{CO}_{2}$ during its combustion will be reabsorbed during the trees growth, which may be an answer for meeting the EU's future goals and challenges. Even though, a lot of effort has been made for implementing biomass as an alternative source of fuel, the EU has not conclude to an efficient energy production from a specific source of biomass. Therefore, more research is needed in order to accomplish a feasible energy production from biomass.

\subsection{Biomass utilisation (Poland, Sweden, Italy)}

Poland has a large potential in case of biomass utilization. During the year 2012, the energy produced from biomass represents $82.2 \%$ of Poland's total renewable energy production and $9.6 \%$ of the national energy production which accounts for $81 \mathrm{TWh}$ [3]. Biomass is mainly utilized by combustion and co-combustion in Mega-plants such as biomass co-combustion Rybnik (PF Pulverised Fuel combustion $1775 \mathrm{MW}_{\mathrm{el}}-11.05 \%$ biomass usage by weight) and Połaniec biomass power plant (CFB Circulated Fluidized Bed $205 \mathrm{MW}_{\mathrm{el}}$, fuel: mix of forestry biomass, seeds, sunflower husk and straw) [4,5]. The forestry (mainly waste from wood industry), agriculture (straw mixture, organic waste), waste biomass are main source of biomass in Poland [3].

Biomass in Sweden is mainly represented by forestry biomass, agriculture, waste biomass from paper and pulp industry, sawmills which generates huge quantities of biowastes [6]. In 2011 total energy production from biomass and wastes reaches $129 \mathrm{TWh}$ which corresponds $11.1 \%$ of total national energy production [7]. For consideration deserve Swedish biomass gasification power plants such as: GoBiGas/Gothenburg indirect gasification $32 \mathrm{MW}_{\text {th }}$ (the target is to reach $100 \mathrm{MW}_{\text {th }}$ ) fuel: solid biofuels, forestry wastes; Värö by Götaverken/Värö fluidised bed gasification $28 \mathrm{MW}_{\text {th }}$ fuel: dried bark and wood wastes [8].

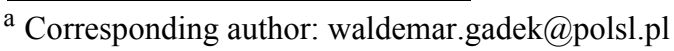


Biomass gasification market in Sweden is growing rapidly and has a significant potential [8].

Italy has large biomass resources mainly straw biomass, olive and grape residues, pruning's and forestry biomass. In 2010 energy production from biomass reaches the $73.3 \mathrm{TWh}$ which corresponds to $20.6 \%$ of total national energy production [9]. Total thermal power installed in biomass power plant amounts 1,243 MW [10]. Considering the different distribution of forestry and the different climate situation in Italy, the district heat production from solid biomass is mainly concentrated in the northern regions [11]. Furthermore, since residual biomass are wide dispersed in the Italian territory, the national government has encouraged the installation of sub-megawatt plants for combined heat and power production (CHP). For these reasons, especially in the southern Italians regions, residual biomass from agro-food industries have a greatunexploited potential.

\subsection{Alternative technologies to combustion}

According to climate change the new alternative technologies for energy production are essential. It is associated with reduce of carbon dioxide emission. Combustion of fossil fuels (coal, oil, natural gas) increase the greenhouse effect [12]. The first easiest idea to reduce the emission of $\mathrm{CO}_{2}$ was to use biomass instead of coal. However, combustion and co-combustion of biomass mainly waste biomass or agro-biomass is associated with biomass feeding, pre-treatment problems, fouling, corrosion, modification of boiler operation and flue gas cleaning section, modification of heat transfer in the boiler [13]. These serious challenges contributed to the research for other technologies of biomass utilisation. Finally the application of pyrolysis and gasification process might be promising alternative to combustion. The research to improve efficiency of gasification and pyrolysis process is essential.

\subsection{Pyrolysis and gasification of biomass}

Gasification is thermochemical process that enable to convert solids or liquids in a value added gas product (syngas). This process use an oxygenating agent, with an equivalence ratio usually between $0.2-0.4$, depending on the process temperature $\left(700-1200^{\circ} \mathrm{C}\right)$.

Pyrolysis is a process similar to gasification, but in comparison to other technologies of fuel thermal conversion, pyrolysis occurs at relatively low temperature range $\left(300-600^{\circ} \mathrm{C}\right)$ and in the absence of an oxidizing agent.

The advantages of using pyrolysis and gasification systems instead of direct combustion of solid biomass are related to environmental aspects and to the possibility of polygeneration. Indeed, syngas produced from biomass gasification or pyrolysis can be used for combined synthesis of high-value chemicals synthesis and for energy production. Other products: liquid tars and solid char may be used as direct fuels or to make new products like ethanol from tars or fertilizers from char. From the environmental point of view, it has to pointed out that gasification plants produce a lower amount of major air pollutants, like $\mathrm{SO}_{2}$, $\mathrm{NO}_{\mathrm{x}}$ and particulates, than direct combustion [14]. Differences between chemical composition of biomass and coal affects not only gaseous phase but mineral phase as well. Fly ash from biomass combustion contains much more potassium, magnesium and calcium, simultaneously less iron, aluminum and silicon [15]. Biomass combustion may cause severe problems concerning fly ash agglomeration and corrosion of heat exchanging surfaces. Therefore, gasification and pyrolysis are better technologies for thermal conversion of biomass containing high amounts of chlorine and alkali metals.

In addition, gasification is preferable route for generation of electricity from small plants in remote areas, where gasification/internal combustion engine systems are more convenient than combustion/steam engine.

\section{Methodology}

\subsection{Small scale fix bed reactor}

Both gasification and pyrolysis experiments has been conducted on a semi batch type fix bed reactor located at the Royal Institute of Technology, Stockholm, Sweden. The reactor has a cylindrical shape with $0.0254 \mathrm{~m}$ inner diameter and $1 \mathrm{~m}$ total length, while inside the reactor, a fine stainless steel grid has been placed on the middle of the reactor's length. For every experiment, 10 grams of biomass has been placed on that grid in order to make sure that the heated $\mathrm{N}_{2}$ in case of pyrolysis and the air in case of gasification experiments was passing through the reacted material. High purity nitrogen has been used as inert gas before every experiment in order to purge the whole reactor from the remainings of $\mathrm{O}_{2}$. The reactor was heated with a $1 \mathrm{~kW}$ cylindrical electric furnace to the desired temperature, while a $\mathrm{K}$ thermocouple was attached to the outer wall of the reactor, close to the position of the grid $(0,5 \mathrm{~m}$ from the top of the reactor) for controlling the temperature of the furnace.

\section{Pyrolysis experiments}

The pyrolysis experiments were conducted for the temperatures of $400^{\circ} \mathrm{C}, 500^{\circ} \mathrm{C}$ and $600^{\circ} \mathrm{C}$ for three examined fractions of biomass. During each experiment, the reactor with the grid and the sample was placed inside furnace which initially was at room temperature. A stable flow of $50 \mathrm{ml} / \mathrm{min}$ of $\mathrm{N}_{2}$ was introduced from the top of the reactor for sufficient time before the heating up in order to make sure that there was no oxygen inside the reactor before every experiment. Additionally, the facility was leak tested in order to make sure that no leaks existed on the different connections. During the heating up of the furnace, from the $100^{\circ} \mathrm{C}$ until the desired temperature, the gas produced plus the additional nitrogen that was added on the system was collected on the first container. When the furnace has reached to the desired temperature, the produced gas was collected on the second gas container. Both containers were initially filled up with water, so during the gas collection, the volume of gas collected was measured according to the water displaced from the containers. Each 
sample of biomass was kept at the desired temperature for 15 minutes in total. On the bottom of the reactor, before the gas collecting containers, three empty gas washing bottles was connected and placed on a cooling bath of $0^{\circ} \mathrm{C}$ for condensing the oils and the gases produced. Finally, the gas composition collected on the containers was analyzed.

\section{Gasification experiments}

The gasification experiments were conducted for the temperatures of $700^{\circ} \mathrm{C}$ and $800^{\circ} \mathrm{C}$ for the three examined biomass fractions. The reactor, the grid and the sample was again placed on the same position inside the furnace while nitrogen was used to purge the remaining $\mathrm{O}_{2}$ for sufficient time before the heating up. During the heating up, the nitrogen was switched to air with a stable flow according to the chosen $\lambda$ for each biomass type. All the products of the gasification process were passing through two gas washing bottles placed on a cooling bath for condensation of the condensable fractions and finally they were passing through a gas washing bottle filled up with isopropanol in order to trap any tar remained. Finally, a portable gas chromatographer was sampling the gas produced every three minutes. The examined cases are summarized on the graph (Figure 5.), an average gas composition for temperature range from around $600{ }^{\circ} \mathrm{C}$, when gas analysis showed first combustible gas components, up to desired temperature $800^{\circ} \mathrm{C}$.

\subsection{Micro GC gas analysis}

The gas collected on a gas containers and the online gas composition measurement during the gasification process was analyzed with an Agilent 490 Micro gas chromatographer (GC). The micro-GC is equipped with four channels and each one of them contain different columns and a thermal conductivity detector. The first channel has a Molsieve $5 \AA$ column, which is able to detect the permanent gases $\left(\mathrm{H}_{2}, \mathrm{He}, \mathrm{O}_{2}, \mathrm{~N}_{2}, \mathrm{CH}_{4}, \mathrm{CO}\right)$, the second channel is equipped with a $\mathrm{CP}$ PoraPlotU column which mainly separates and analyze the $\mathrm{CO}_{2}, \mathrm{H}_{2} \mathrm{~S}$ and $\mathrm{C} 2$ hydrocarbons, while the third channel has a $\mathrm{CP}$ PoraPlotU column, which can detect and analyze the $\mathrm{C} 3$ and $\mathrm{C} 4$ hydrocarbons. The final channel has a CP-Sil 5 CB column for detection of higher molecular weight hydrocarbons. Argon was used as a carrier gas on the first two columns while helium was used on the third and fourth column. The method of analysis used for the analysis of the gases was lasted for two minutes on stable temperature conditions while the total sampling time was chosen to be 30 seconds, for more accurate results.

\subsection{Materials}

\section{Wood}

Wood is widely used for energy production in Poland and Sweden. Particularly important is utilization of forestry waste, wood chips, and waste from wood and paper industry. Polish and Swedish furniture sector produces a large quantities of wooden bio-wastes which have to be utilized. For experiments wooden mixed waste from wood industry was chosen. They are characterized by high LHV $18,5 \mathrm{MJ} / \mathrm{kg}$, low ash content $0,31 \%$ compared to other investigated fuels. Particles were sieved in the order to obtain a homogenous mixture $(0.7<\mathrm{d}<1.4)$. The biomass properties comes within the scope of literature data [16].

\section{Oat straw}

Straw is a mixture of dried stalks and blades after the ripe crop threshing. Straw is mainly a byproduct from a plant production on farmlands. In Poland, despite a wide straw use in agriculture, a significant overproduction is observed, which might be used for power production purposes. It is assumed that due to variable straw resources, it would be possible to use approx. $30-50 \%$ of existing straw resources. According to previous assumptions, power industry can take advantage of $1.74-2.90$ Mtonnes of dry straw pulp per year [17].

In the experiment, oat straw $(\mathrm{d}<1 \mathrm{~mm})$ was selected as an example of agricultural wastes used for power industry purposes. In comparison to other fuels selected for the experiment, oat straw has quite high ash, sulfur and chlorine content (Table 1). Therefore, it is a difficult fuel for direct combustion.

\section{Citrus waste}

Agricultural wastes in Italy are of great interest because of the lack of intensive forest presence in some area of the country, if compared with northern countries in Europe. Furthermore, Italy is well known worldwide for the food industry due to the large variety of typical agricultural activities. Citrus pulp and peels are residues from agro-industrial activities that are typical of the Mediterranean area, and it implies a significant cost for juice manufacturer, because of its fermentability and the high residue yield [18]. This waste was selected because to date, it is not enough exploited for energy production and it has a different structure and composition with respect to others well known lignocellulosic residues in the field of biomass gasification. In this work, dried citrus wastes were supplied by a company in Sicily (Italy), where the total amount of citrus wastes for the region is close to $33000 \mathrm{t} /$ year (dry matter) [19].

Table 1. Proximate and elemental analysis biomass samples.

\begin{tabular}{|c|c|c|c|c|}
\hline Parameter & Unit & $\begin{array}{c}\text { Oat } \\
\text { straw }\end{array}$ & $\begin{array}{c}\text { Citrus } \\
\text { wastes }\end{array}$ & Wood \\
\hline $\begin{array}{c}\text { Carbon content, } \\
\mathrm{C}^{\text {ar }}\end{array}$ & $\%$ & 46,39 & 41 & 50,70 \\
\hline $\begin{array}{c}\text { Hydrogen } \\
\text { content, } \mathrm{H}^{\mathrm{ar}}\end{array}$ & $\%$ & 5,83 & 5,6 & 6,10 \\
\hline $\begin{array}{c}\text { Nitrogen content, } \\
\mathrm{N}^{\text {ar }}\end{array}$ & $\%$ & 0,56 & 0,8 & 0,18 \\
\hline $\begin{array}{c}\text { Sulfur content, } \\
\mathrm{St}^{\text {ar }}\end{array}$ & $\%$ & 0,11 & 0,1 & 0,012 \\
\hline $\begin{array}{c}\text { Chlorine content, } \\
\mathrm{Cl}^{\text {ar }}\end{array}$ & $\%$ & 0,147 & - & - \\
\hline \begin{tabular}{c} 
Ash content, $\mathrm{A}^{\mathrm{ar}}$ \\
\hline
\end{tabular} & 7,6 & 8,2 & 0,31 \\
\hline
\end{tabular}




\begin{tabular}{|c|c|c|c|c|}
\hline $\begin{array}{c}\text { Moisture content, } \\
\mathrm{W}^{\text {ar }}\end{array}$ & $\%$ & 4,83 & 7 & 8,47 \\
\hline $\mathrm{HHV}$ & $\mathrm{kJ} / \mathrm{kg}$ & 18170 & 15212 & 20460 \\
\hline $\mathrm{LHV}$ & $\mathrm{kJ} / \mathrm{kg}$ & 16970 & 14082 & 18572 \\
\hline
\end{tabular}

\section{Results and discussion}

Gas pyrolysis yield $\left(\%_{\mathrm{w} t} / \mathrm{wt}\right)$ is shown in Figure 1. For different biomasses and different temperatures (400, 500 and $\left.600^{\circ} \mathrm{C}\right)$. Wood gas yield increased slightly from 400 to $500^{\circ} \mathrm{C}(3.24 \%)$ and it was almost constant from 500 to $600^{\circ} \mathrm{C}$ but in the same temperature range oat straw showed a marginal increase (3.9\%). Citrus peel had the highest gas yield increase as the temperature increases, varying from 14.17 to $30.89 \%$ (from 400 to $600^{\circ} \mathrm{C}$ ). The last was also the highest gas yield value among the investigated biomass. This behavior could be explained with the low concentration of lignin in citrus peel [18], resulting in an easier decomposition process at higher temperatures $\left(600^{\circ} \mathrm{C}\right)$, when the cellulose decomposition is almost complete [20]. Figure 2 . shows pyrolysis gas LHV for the different biomass at different temperatures. It can be noticed that the higher heating value $\left(17.1 \mathrm{MJ} / \mathrm{m}^{3}\right)$ was obtained for wood at $600^{\circ} \mathrm{C}$, which is the biomass with the higher carbon content. Syngas low heating values were also evaluated for gasification test for all the samples at 700 and $800^{\circ} \mathrm{C}$, which results are shown in Figure 3. The highest LHV was observed for wood, that was $2.26 \mathrm{MJ} / \mathrm{m}^{3}$ at $700^{\circ} \mathrm{C}$, while for citrus peel and oat straw it was 2.01 and $1.94 \mathrm{MJ} / \mathrm{m}^{3}$ respectively. Gas composition was also evaluated for both pyrolysis and gasification tests. Examples of gas composition are shown in Figure 4 and Figure 5 for pyrolysis at $600^{\circ} \mathrm{C}$ and gasification at $800^{\circ} \mathrm{C}$, respectively.

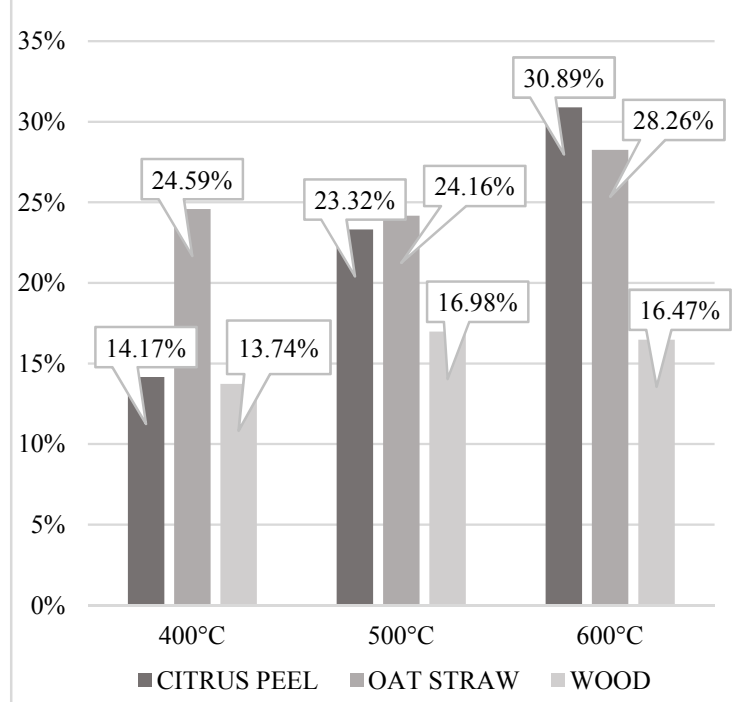

Figure 1. Pyrolysis gas yield (\%wt/wt) for citrus peel, oat straw and wood at $400^{\circ} \mathrm{C}, 500^{\circ} \mathrm{C}$ and $600^{\circ} \mathrm{C}$

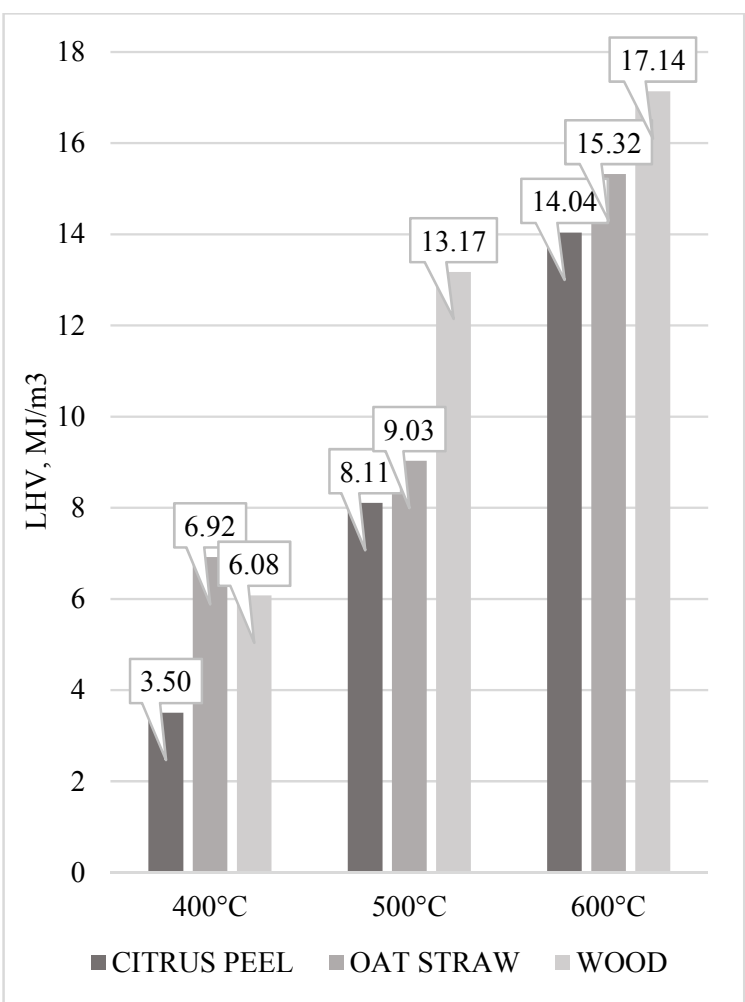

Figure 2. Normalized pyrolysis syngas LHV $\left[\mathrm{MJ} / \mathrm{m}^{3}\right]$ for citrus peel, oat straw and wood at $400^{\circ} \mathrm{C}, 500^{\circ} \mathrm{C}$ and $600^{\circ} \mathrm{C}\left(\left[\mathrm{N}_{2}\right]\right.$, $\left.\left[\mathrm{O}_{2}\right]=0\right)$

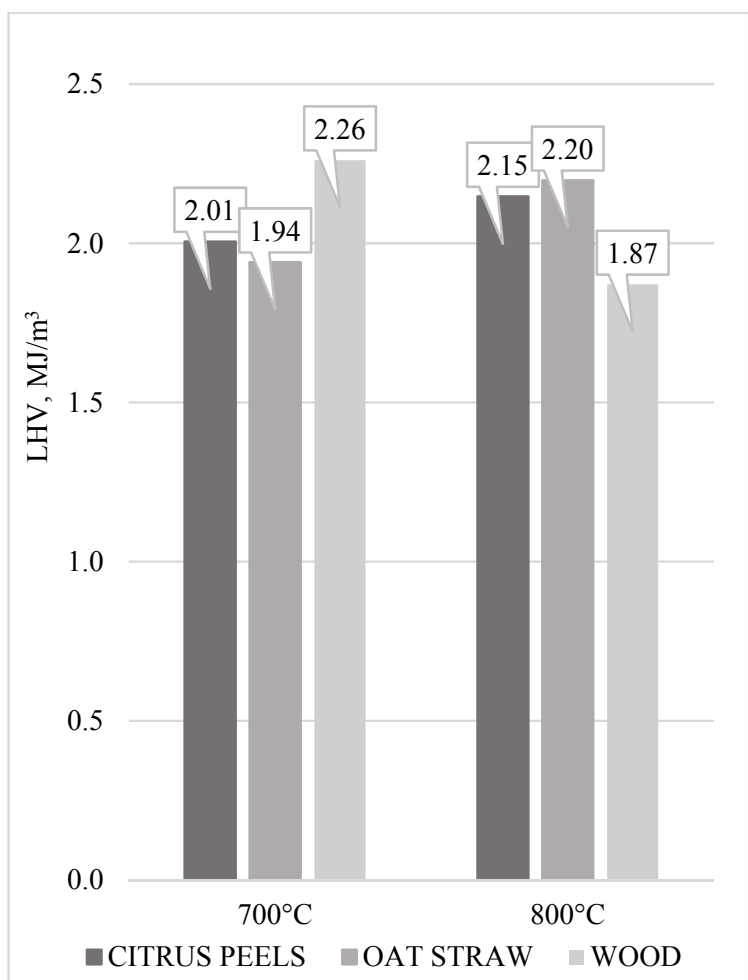

Figure 3. Gasification syngas LHV $\left[\mathrm{MJ} / \mathrm{m}^{3}\right]$ for citrus peel, oat straw and wood at $700^{\circ} \mathrm{C}$ and $800^{\circ} \mathrm{C}$ 


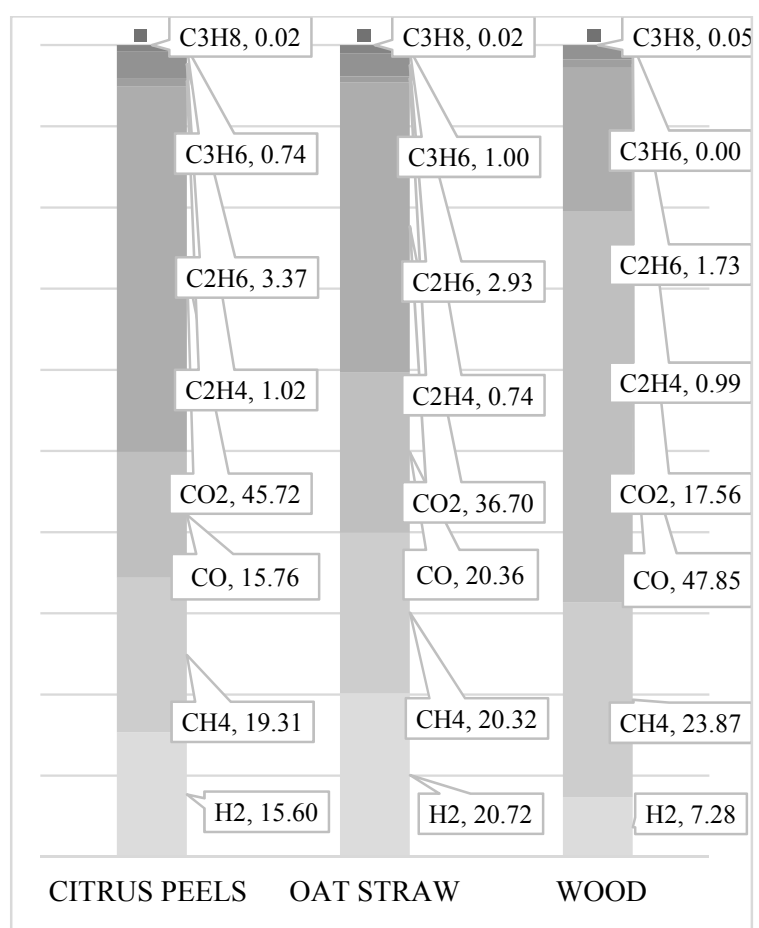

Figure 4. Normalized pyrolysis syngas composition for citrus peel, oat straw and wood at $600^{\circ} \mathrm{C}\left(\left[\mathrm{N}_{2}\right],\left[\mathrm{O}_{2}\right]=0\right)$

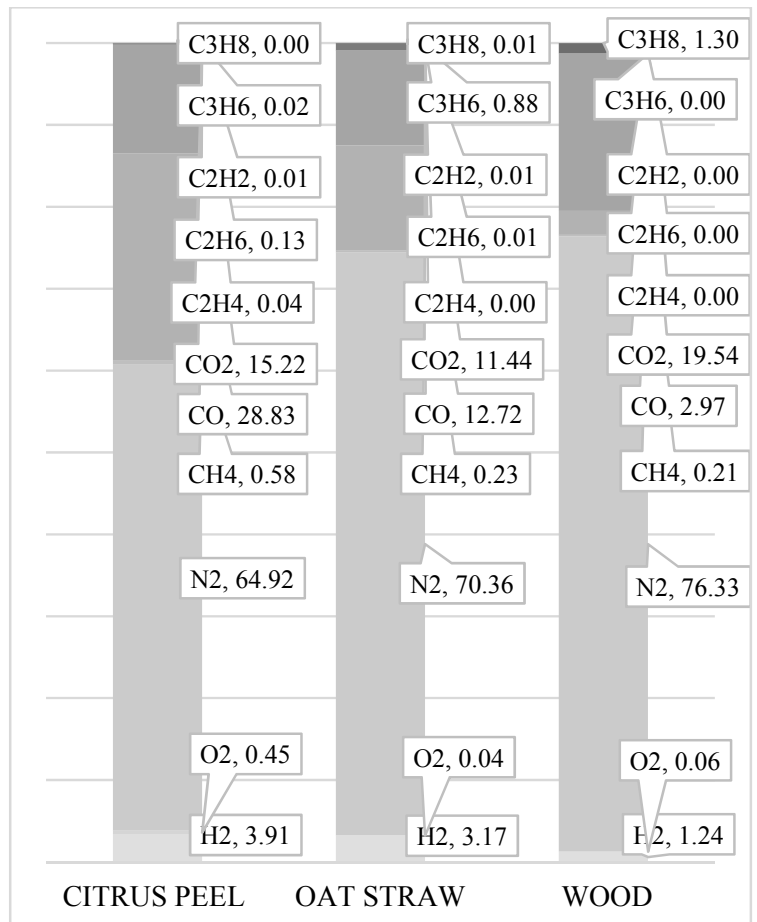

Figure 5. Gasification syngas composition for citrus peel, oat straw and wood at $800^{\circ} \mathrm{C}$

\section{Conclusions}

The behaviour of different biomass from different European regions under air gasification and pyrolysis conditions was studied in order to evaluate the possibility of using alternative local feedstocks that are typical of different continental areas. Results showed that oat straw and citrus peels can be exploited as feedstocks for pyrolysis and gasification conversion, as well as wood. Although citrus peel showed the worst performance during pyrolysis tests in terms of LHV, it had higher gas yield $(30.89 \%)$ than wood $(16.47 \%)$ and oat straw $(28.26 \%)$ at $600^{\circ} \mathrm{C}$. Gasification tests showed that wood produced the highest syngas LHV $\left(2.26 \mathrm{MJ} / \mathrm{m}^{3}\right)$ and oat straw the lowest $\mathrm{LHV}\left(1.94 \mathrm{MJ} / \mathrm{m}^{3}\right)$ at $700^{\circ} \mathrm{C}$. It can be concluded that residual biomass, such as oat straw and citrus peel can be considered as alternative to or combined with wood for thermochemical biomass conversion.

\section{References}

1. EU Council, EUCO 169/14, (2014)

2. D. Bourguignon, EPRS, Members' Research Service, PE 568.329 (2015)

A. Piwowar, A. Dzikuć, Renewable and Sustainable Energy Reviews, 54, 415-420, (2016)

3. EDF Polska S.A. http://www.edfrybnik.pl/art,646,strukturapaliw.html (access 18.04.2016)

4. ENGIE Energia Polska S.A. http://www.gdfsuezenergia.pl/dokument/20130607/30

5. (access 18.04.2016)

6. W. Wei, P. Mellin, W. Yang, C. Wang, A. Hultgren, H. Salman, Report I, Swedish Energy Agency, 358191, (2013) https://www.divaportal.org/smash/get/diva2:681739/FULLTEXT01.p df, (access 18.04.2016)

7. OCED/IEA, Energy Policies of IEA Countries Sweden $2013 \quad$ Review, (2013) http://www.iea.org/publications/freepublications/pub lication/Sweden2013 free.pdf (access 18.04.2016)

8. Ridjan, M. B. Vad, D. Connolly, Aalborg University Denmark, (2013) http://vbn.aau.dk/files/123284438/A_review_of_bio mass_gasification_technologies_in_Denmark_and_S weden.pdf (access 18.04.2016)

9. OCED/IEA, Energy Policies of IEA Countries - Italy $2009 \quad$ Review, (2009) http://www.iea.org/publications/freepublications/pub lication/italy2009.pdf (access 18.04.2016)

10. GSE, Statistical Report 2011 - Renewable Energy power Plants in Italy, (2011) http://www.gse.it/it/Dati\%20e\%20Bilanci/GSE_Doc umenti/ENG/Italy\%20RES\%20Stastistical\%20Repor t\%202011\%20WEB\%20def\%2015-112012\%20\%20tag.pdf (access 18.04.2016)

11. F. Di Mario, G. Braccio, V. Pignatelli, N. Colonna, F. Zimbardi, Quaderni ENEA: Biomasse e Bioenergia. ENEA, Rome, 2011

12. IEA/OCED, $\mathrm{CO} 2$ Emission from Fuel Combustion, (2014)

13. S. Kalisz, M. Pronobis, D. Baxter, Energy, 33, 17701778, (2008)

14. P. Basu, Biomass Gasification, Pyrolysis and Torrefaction - Practical Design and Theory Second Edition, (Oxford: Academic Press Elsevier 2013) 
15. T. Fulczyk, E. Głowacki, Energetyka, (2010) http://www.cire.pl/pliki/2/ProblemyEksploatacyje_E F_IOS_biomasa.pdf (access 18.04.2016)

16. J. Wandrasz, A. Wandrasz, Paliwa formowane, (Wyd. Seidel Przywecki sp. z o.o., 2006)

17. G. Wiśniewski, K. Michalowska-Knap, A. OniszkPoplawska,: Określenie potencjału energetycznego rejonów Polski w zakresie odnawialnych źródeł energii- wnioski dla Regionalnych Programów Operacyjnych na okres programowania 2014-2020, (2011) https://www.funduszeeuropejskie.20072013.gov.pl/dzialaniapromocyjne/Documents/raport OZE_druk_korekta_m.pdf (access 18.04.2016)

18. F. R. Marìn, C. Soler-Rivas, O. Benavente-Garcì, J. Castillo, J. A. Perez-Alvarez; Food Chem., 100, 2, 736 - 741 (2007)

19. ISPRA, Studio sull'utilizzo di biomasse combustibili e biomasse rifiuto per la produzione di energia (Italy, ISPRA, 2010)

20. P. Giudiciani, G. Cardone, R. Ragucci ; Journal of Analytical and Applied Pyrolysis, 100, 213-222 (2013) 